\title{
Transnational Christianity and Converging Identities
}

\author{
Arabic Protestant Churches in New Jersey
}

\author{
Deanna Ferree Womack
}

Global migration is transforming the character of American Christianity, prompting recent studies of Asian, African, and Hispanic/Latino(a) Christian diasporas in the United States. The relative inattention to Arab American Christian communities, however, reflects the mistaken perception that Christianity is stagnant in the Middle East and of little importance among Arabs in the Us. In reality, the continuing presence of vibrant Christian communities has enriched Middle Eastern society, and Arab Christians have remained an active part of intellectual, cultural, and political life in the region (Sharkey 2012: 7,15$)$. Although the percentage of Christians in the Middle East and North Africa has declined relative to the majority Muslim population, Christianity in this region has charted consistent numerical growth for centuries. Its Christian population tripled in size between 1910 and 2010 (Johnson and Chung 2004: 181; Pew Forum 2011). In addition, more than a century of emigration from the Middle East and North Africa has resulted in a significant Arab Christian presence within Europe and the Americas. The majority of Arab Americans are Christians, but the uncritical association of Arabs with militant Islam has overshadowed this fact, doing an injustice to Arab Christians and Muslims alike. In order to gain a deeper understanding of Arab American Christianity as a lived reality, this study examines the histories, relationships, and experiences of Arab Christians in the United States. Addressing Arab Protestant churches specifically, it answers the following questions: What do the transition experiences mean for immigrants who join Arabic speaking churches in the us? What reference points help them reformulate a sense of identity?

This chapter focuses on Arabic churches in New Jersey as a window into the wider Arab American Protestant experience. The designation "Arabic churches" indicates Protestant congregations that worship in the Arabic

* A special word of thanks is due to Michael Poon, Martha Frederiks, and Dorottya Nagy for helpful feedback on earlier drafts of this contribution.

Originally published in Mission Studies 32 (2015) 250-270.

(C) DEANNA FERREE WOMACK, 2016 | DOI 10.1163/9789004326156_008

This is an open access chapter distributed under the terms of the CC-BY-NCLicense, ree Womack - 9789004326156 
language. ${ }^{1}$ This is a worthwhile subject of investigation because little scholarship exists on Arab American Christians and their churches' role in the resettlement process (Suleiman 2010: 54). In particular, academic publications on Arabic speaking Protestant churches are missing within the small body of literature on Arab American Christianity, most of which focuses on

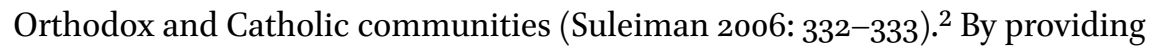
new information about immigrants in Arabic Protestant churches, this essay challenges stereotypical representations of Arabs and points to the reality of Arab Protestant communities in the Middle East and in the us. It also reminds American and European Protestants of their churches' historical ties to Middle Eastern Protestant churches founded by missionaries.

After taking account of historical and demographical information on Arab immigration to the Us and addressing questions of methodology, this chapter presents a study of five Arabic Protestant churches in New Jersey. These churches include the two Presbyterian Church (USA) congregations in the state, another Presbyterian affiliated congregation, one United Methodist church, and one non-denominational congregation. The oldest of these churches dates to the late 196os, while the youngest was formed in 2011. Reflecting state demographics, the members of these Arabic speaking congregations in New Jersey are primarily Egyptians (Arab American Institute 2015). Most have lived in the us for fewer than twenty years and are either first or second generation immigrants. Considering that most studies of Arab American communities focus on the Lebanese populations in New York and Michigan (Suleiman 2010: 51), this chapter contributes a more diverse view of Arab American experience as it examines the challenges and opportunities Arabic speaking Protestant congregations face in New Jersey.

Arab American Christianity: History and Demographics

The first wave of Arab immigrants to the us arrived from Ottoman Syria in the late nineteenth and early twentieth centuries. Ninety percent of these immigrants were Christian, and they established the first Arabic speaking churches

\footnotetext{
1 This contrasts with the ethnic and cultural term "Arab" and the general designation of "Middle Eastern." The church leaders in my focus group used the terms "Arabic church" and "Protestant" to refer to their own congregations, and this essay employs the same terminology.

2 Michael Suleiman's comprehensive bibliography of Arab American experience lists five sources on Arab Protestant churches. The only academic study is Ablahat 1937.
} 
on American soil (Kayal 1983:46,48; Marvasti and McKinney 2004: 27). Syrian immigration peaked in 1914 and came to a near halt after the Johnson-Reed Act of 1924 limited immigration into the Us, especially from non-European countries. A second wave of Arab immigrants from more diverse religious and national backgrounds began in the 1940 s, and their numbers rose dramatically after the Us repealed the quota act in 1965 . With this easing of restrictions, many Arabs immigrated from Lebanon, Palestine, Egypt, Iraq, and Yemen for economic and political reasons (Holsinger 2009: 27,37; Suleiman 1999: 1-2,9). In 1980, when the us Census Bureau first collected statistics on the Arab American population, 610,000 Americans reported Arab ancestry (Brittingham and de la Cruz 2003: 1). This number included recent immigrants and descendants of earlier Arab immigrants.

The us Census Bureau is limited in its ability to reflect the self-identification of Arab Americans because "Arab" is not one of the designated categories for "race" on the standard census form completed by American households every ten years. Up through the 2000 census, estimates for the Arab American population were based on the long census form, which included an additional question about ancestry and space for respondents to write an answer. Just one out of every six households received this longer form (Marvasti and McKinney 2004: 32). The standard form asks only about race, and the Census Bureau expects most Arab Americans to select the category "white," which it defines as the race of people "having origins in any of the original peoples of Europe, the Middle East, or North Africa" (Hickson, Hepler, and Kim 2011: 2). Since the form does not give an option to write in specific ethnic origins under this category, the census cannot accurately measure the Arab American population or determine how many Arab Americans self-identify as white. According to the Census Bureau's yearly American Community Survey (ACs), which replaced the long census form after 2000, 1.5 million Americans claim Arab ancestry (Asi and Beleau 2013: 1). ${ }^{3}$ The Arab American Institute (AAI) disputes this figure, however, because the ACS only surveys a small percentage of us households. AAI estimates that the actual Arab American population is 3.7 million (AAI 2012).

The current religious makeup of the Arab American population is also difficult to determine because the Census Bureau does not ask questions regarding religion. The most recent AAI poll on religious affiliation taken in 2002 shows that 63 per cent of the Arab Americans surveyed self-identified as Christian. Of the survey respondents, 24 per cent identified themselves as Muslim (Sunni,

3 The most recent census of 2010 used only the standard census form. 
Shi'a, and Druze). ${ }^{4}$ According to this survey, the Arab American Christian population is 35 per cent Catholic (Roman Catholic, Maronite, and Melkite), 18 per cent Orthodox (Antiochian, Syrian, Greek, and Coptic), and 10 per cent Protestant (AAI 2002). The majority of Arab American Protestants are affiliated with either the Presbyterian Church (USA) or the Southern Baptist Convention (Haddad 1994: 72).

In 1899 Syrian immigrants affiliated with American Presbyterian missions in Beirut formed the first Arabic speaking Protestant congregation in the Us in Falls River, Massachusetts. It became part of the Presbyterian Church in the United States in 1934. Two other Arabic speaking Presbyterian churches were founded in the early twentieth century in Brooklyn, New York, and in Pittsburgh, Pennsylvania (Presbyterian Church 2011: 3; Haddad 1994: 73). Following the second wave of immigration in the mid-twentieth century, Arab Presbyterians founded a number of new churches in the Us. In 1969, Egyptian immigrants from the Evangelical Church of Egypt (Presbyterian Synod of the Nile) established the first of these Arabic churches in New Jersey. According to Victor Makari, in response to the growing number of Arab and other Middle Eastern Presbyterian immigrants, in 1981 the Presbyterian Church initiated the Advisory Committee for Ministry with Middle Easterners in the USA. Makari, the original chair of this committee, explains that it organized several Arabic and Persian speaking worship communities across the Us. This work eventually led the Presbyterian Church (USA) to create an Office of Middle Eastern Ministries (Makari 2011). The office was founded in 1993 and currently provides spiritual and organizational support to more than 6o Middle Eastern Presbyterian congregations and fellowships, the majority of which are Arabic speaking (Presbyterian Church 2011: 3).

Since the us Census Bureau began reporting statistics on Arab Americans in 1980, New Jersey's Arab American community has tripled, and it remains one of the fastest growing Arab populations in the US (AAI 2015). The Arab presence in New Jersey began in the late nineteenth century in Paterson, which was known as the "Silk City" of America. Syrian migrants who were weavers in their homeland headed the state's silk industry and owned large mills until the Great Depression (Kayal 1977: 22). In the late 196os, New Jersey's Arab American population underwent demographic change with the arrival from Egypt of large numbers of Coptic Christians and a smaller number of Muslims. The Coptic Orthodox Church established in Jersey City in 1970 was the first of a number of Coptic churches founded in major cities across the us (Abdelsayed

4 While the AAI survey classifies the Druze as Muslims, differences of opinions exist on the relationship between the Druze faith and Islam. See Haddad 1991: 111-112. 
1977: 121-122,125). New Jersey's Egyptian population continued to grow, and by 1977 Coptic Christians had become the largest segment in Jersey City (Kayal 1977: 22; Holsinger 2009: 47). Today, Egyptians are the largest Arab group in New Jersey's estimated Arab American population of 85,956 (AAI 2015).

Existing historical scholarship and demographical data on Arabs in America reveal two critical points for consideration. First, despite the common tendency to associate Arabs with Islam, the majority of Arab Americans are Christians. Arab Muslims are the minority within both Arab American and American Muslim populations (Salaita 2006: 9). Second, Arab Christians have deep roots in the United States. In particular, the history of Arab American Protestantism stretches back to the late nineteenth-century relationship between American Presbyterian missionaries and Protestant churches in Syria and Egypt. This information is important for combatting the prevalent view of Arab Americans as dangerous outsiders. According to recent studies, this institutionalized prejudice has resulted in increased acts of anti-Arab racism in the us since September 11, 2001. After nearly a century and a half of Arab American presence in the United States, exclusive expressions of "Americanness" in the media, politics, the business world, and daily American life perpetuate a sense of disenfranchisement among American Arabs (Marvasti and McKinney 2004: 12; Salaita 2006: 4,13; Suleiman 2010: 50,55).

\section{Methodology: Studying Congregations}

As a short-term investigation of Arabic speaking congregations, this study is limited in scope. It does not offer an exhaustive description of Arabic Protestant churches in New Jersey, but it aims to provide a basis upon which future studies might build. In order to add to the small amount of existing scholarship on Arabic American Protestant churches, I adapted the sociological methodology in Studying Congregations: A New Handbook, edited by Nancy Ammerman (Ammerman et al. 1998). Rather than focusing on one congregation, I compared the experiences of transition and identity formation in five Arabic speaking churches. I conducted my fieldwork between March and May, 2011.

In a focus group interview with five pastors and elders from these churches, I drew upon the handbook's framework for studying congregational ecology (the particular socio-political, economic, and religious contexts of churches as living organisms) and culture (a congregation's unique rituals, stories, and ways of understanding communal life; Ammerman et al. 1998: 14-15). I used the handbook's Timeline and Social Network Map activities to gauge conceptions of congregational history and to discover how leaders and members of 
Arabic speaking churches spend time in relationships inside and outside their local congregations (Ammerman et al. 1998: 43-47,50-55). By beginning my investigation with church leaders, I gained a pastoral assessment of members' concerns and broad insight into their churches as a whole. Recognizing that leaders' views may differ from the perspectives of church members, however, I supplemented the information from this focus group with visits to church worship services, follow-up interviews, and informal conversations with members.

My main source of information on inter-generational issues in Arab immigrant churches is another focus group discussion with eighteen youth at the Arabic American Evangelical Church in Jersey City. This is the largest and longest-operating youth group in the five churches I studied. While these youth in Jersey City cannot speak for their peers in other New Jersey churches, the information they provided is corroborated by the pastors I interviewed and by conversations with parents and youth in other churches. As I present the outcomes of my research on congregational ecology and culture in the following section, I take a comparative approach that focuses on the important commonalities and distinguishing differences between the churches studied. ${ }^{5}$ In the research findings below, the names of my focus group participants are anonymized.

\section{Research Findings: Congregational Ecology and Culture}

Three of the churches in this study are located in northern New Jersey in close proximity to New York City. The oldest of these, the Mideast Evangelical Church (MEC) of Jersey City, began in 1969 when a small group of Egyptian Presbyterians organized house church meetings. As the congregation grew, it was given a worship space in Jersey City's Old Bergen Church, a united church of the Reformed Church in America and the Presbyterian Church in the United States. The congregation joined the Presbyterian Church in 1976 and bought its own building in the late 1980 os (Faragalla 2011). ${ }^{6}$ MEC's membership is around 100 and most members are immigrants from Egypt (Focus Group 2011). The Arabic American Evangelical Church of Jersey City split from MEC in 2008. The great majority of its $5^{0}$ members are Egyptian and a few

5 I drew upon my knowledge of Arabic during church visits but conducted all interviews in English.

6 At the time of this interview Joseph Faragalla, Executive Presbyter of the Palisades Presbytery, was assisting MEC with worship while the church conducted a pastoral search. 
come from Jordan (Marzouk 2011). ${ }^{7}$ Rivers of Life is an Arabic speaking United Methodist church in Bayonne. Since the church began in 2003, its membership has risen to 6o. Most members are Egyptian and a small number come from Jordan and Syria. In central New Jersey, the non-denominational Christian Arabic Church in East Brunswick came into being in early 2011. Nearly all of its twenty-five members are Egyptian immigrants. The Arabic Evangelical Church of South Jersey located in Moorestown began as a church of the PC(USA) in Narberth, Pennsylvania, in 1971. Many of its thirty members are Egyptian, but others are Jordanian, Lebanese, Syrian, Iraqi, Palestinian, and Israeli Arabs. In all five churches, the majority of adult members are first generation immigrants. These members include recent immigrants and those who have lived in the Us for ten to twenty years. In each of the three Presbyterian affiliated congregations, a small number of members have resided in the us for more than twenty years (Focus Group 2011).

\subsection{Ecology/Congregation in Context}

During the focus group discussion of their churches' historical timelines, pastors and church leaders placed differing emphases upon the memories they recounted. As a worship leader and founding member of his church, Magdy measures his time in the us according to the changes in worship music since he arrived in 1995. His story overlaps the history and frequent divisions of at least six churches in New York and New Jersey. Magdy's current congregation formed after 80 percent of the members of his previous church separated from their pastor. It was without a name, pastor, or building at the time of our focus group meeting. Within the next month, however, the congregation began renting a worship space in a Korean American church and chose the name Christian Arabic Church in East Brunswick. Magdy stresses his new church's need for a carefully crafted governing structure. "We're going to make bylaws," he says. "We're going to make a constitution, and then I believe... if we have an agreement between us, that would avoid any conflicts" (Focus Group 2011). When I attended this church's first worship service and congregational business meeting in its rented space, the church elders expressed a similar conviction. At this formative moment in the congregation's history, they discussed adopting a faith statement and rules of participatory government, and they

7 Safwat Marzouk, pastor of AAEC, was unable to attend the focus group meeting, but I interviewed him privately. The fifth member of the focus group, Ayad, had assisted with worship at AAEC and remained involved in the church. 
decided to delay their pastoral search for a year in order to develop a solid church structure.

Eid, pastor of Rivers of Life in Bayonne, describes how his career as a United Methodist minister began when his non-denominational Arabic congregation rented a worship space from a Methodist church in 2003. The United Methodist Church (UMC) soon incorporated his congregation into its denomination and sent him to seminary. In 2005, the UMC made him senior pastor over the "American church" that shared the building with his Arabic congregation. Some members of this church initially hesitated to have an Arab pastor, and Eid believes that the September 11 attacks influenced such views. Eid's authority as a pastor was later validated at a UMC annual conference that recognized his preaching and outreach to Muslim families who attended his Arabic service and ended up joining the church (Focus Group 2011).

Amin, a Presbyterian Church (USA) pastor, emphasizes his church's denominational affiliation and the way denominational standards help balance church leadership and safeguard against divisions. Amin explains, "I am the leader and yet I am limited in my ability to go beyond my boundaries in making decisions." With its Presbyterian polity, his church has remained united since 1971 when a group of Egyptian immigrants founded the original congregation in Narberth, Pennsylvania. In 2006 the congregation relocated to southern New Jersey to become part of the First Presbyterian Church of Moorestown, where Amin is the member of the pastoral staff responsible for the Arabic congregation. In June 2010, the church accepted twenty-five members as founding members of the Arabic Evangelical Church of South Jersey. While the church recently formed its first task force for international mission, it has been involved in local outreach since the beginning. Amin recalls that the church in Narberth encouraged the establishment of the Mideast Evangelical Church (MEC) in Jersey City in 1976 and provided the church with Bibles and hymnbooks (Focus Group 2011).

Fouad, an elder at MEC, does not focus on his congregation's early history but describes the services it currently offers. He views the church as a welcoming place for people who have just moved from Egypt, like he did in 2005. The worship and preaching are also significant attractions for him, and he emphasizes the congregation's plans to sponsor summer mission trips to San Francisco, Haiti, and Egypt (Focus Group 2011). Despite this ability to welcome new immigrants and to reach out beyond its walls, the church was split in 2008. The members who left MEC established the Arabic American Evangelical Church, which is not a congregation of the PC(USA) but has looked to Egyptian Presbyterian pastors for leadership. The congregation worships in a local Lutheran church 
and has instituted a hybrid form of worship that brings together the church's Arabic speaking adults and English speaking youth (Marzouk 2011).

This focus group discussion of congregational timelines did not provide a comprehensive historical account of any of these churches, but it revealed what was initially important in the church leaders' memories. Notably, the participants focused more on internal congregational actions rather than local or national events, economic concerns, or political realities that affected their church members. With regard to external matters, Eid and Amin emphasized important denominational relationships that connected their Arabic congregation to an English speaking church, and the focus group discussion revealed that all five congregations had shared a building with another local congregation. Magdy compared worship music styles in Egypt to his experience of praise music in the US, and Eid mentioned September 11 as a concern for his English speaking congregation. When I asked directly whether anything in Middle Eastern or American history had affected their churches, Amin quickly responded, "September 11." He explained the stigma attached to a person's physical appearance as an Arab in America, whether Christian or Muslim, saying, "There is a suspicion that you are not a good person, which is really painful, but that's the truth" (Focus Group 2011).

The Social Map activity also reflected the importance of these churches' congregational and denominational connections. Church leaders drew maps of their personal and pastoral relationships, and all of them highlighted links with churches in the New Jersey and New York City areas. The Arabic Evangelical Church of Moorestown, for example, is strongly related to other members of the Presbytery of West Jersey and to the Mideast Evangelical Church in Jersey City. Eid, who has national ties within the United Methodist Church, was the only participant to list church connections in areas of the us outside of New Jersey and New York City. Magdy's map included previous churches he has attended and churches whose pastors are advising his current congregation. Fouad's map reflected his experience of working in an area with a high immigrant population. His relationships include Muslim and Hindu coworkers, Egyptian housemates, and other Egyptians who attend a nearby Coptic Orthodox Church. Living in Jersey City, he is in frequent contact with other Arabic speakers, and although he speaks English he is most comfortable in Arabic. The situation for Arabs in southern New Jersey, Amin explains, is different. His church members do not live in close proximity to one another, and some come from an hour away to be a part of the congregation. Because the Arabic speaking community is spread out, daily life necessitates stronger relationships with Americans of all backgrounds and a higher proficiency in English. Amin explains that his congregation is also unique because "unlike 
churches in north Jersey, they come from many different countries" (Focus Group 2011). Ayad, a Presbyterian pastor from Egypt, has maintained ties with all five Arabic congregations while pursuing graduate studies in theology. He points out the interconnected nature of Arabic speaking Protestant churches in New Jersey and notes that most Arab pastors he knows "are working among multiple congregations in one way or another." Ayad himself assisted the Arabic American Evangelical Church in Jersey City and the Christian Arabic Church in East Brunswick when both churches were without a pastor. Stressing his connection with the seminary in Cairo where he plans to teach after his graduation, he was the only participant in the focus group who listed Egypt on his social map (Focus Group 2011).

My visit in Jersey City with the Arabic American Evangelical Church youth group, whose members range from sixteen to twenty-eight years of age, offered a different perspective on congregational memory and social relationships. The youth group marks its time according to the location of their group meeting, which moved from their original Mideast Evangelical Church attic to a Catholic school to house meetings and then to a local Lutheran church. They also describe their activities outside of the weekly youth meeting:joint worship with a local Arab Methodist youth group, food pantry volunteering, outreach at Bayonne Park, Vacation Bible School, youth retreats, and family conferences. These young people recall the two splits the group experienced in 2002 and 2008, and the various pastors and speakers who have led their youth meetings. Partly as a result of church divisions, they have not had a consistent youth leader, and some of the youth noted the confusing variety of theological teachings passed on by their numerous leaders. Nevertheless, they see progression from their earliest meetings to the emergence of a youth-led praise band and the regular attendance of the entire group at youth meetings. Some of them also describe tuning in to events in Egypt and praying for the political situation there. Their Social Map activity reveals these youth spend the greatest amount of time with family, church, friends, and school. Only one participant listed anything outside of the local context, and he included extended family in Egypt as well as international mission trips to Haiti and Panama. In contrast, the map created by an Egyptian graduate student who joined the group that evening but is not a regular member shows a different set of social connections. After one year in the Us, his social network includes international and Egyptian graduate students, two New Jersey churches he has visited, and his wife, daughter, and friends who are in Egypt. The youth group members, however, are part of a close-knit community that has settled in the us. They describe the church and youth group as their family and explain that in fact many of the church members are relatives (AAEC Youth 2011). 


\subsection{Congregational Culture and Identity}

Interviews and church visits revealed other influences upon identity formation not included in the timelines and social maps. During these two activities, church leaders and youth focused on internal congregational concerns and relationships within the Us, but this does not necessarily indicate they have cut ties with their roots. Immigrants carry their native cultures with them, and their past experiences become reference points for evaluating new situations. In the area of music, for example, Magdy points out that the quiet, reverent approach to worship in the Coptic Orthodox Church has influenced Egyptian Protestant views of worship, especially for those who come from Orthodox backgrounds. He notes the changes in Christian worship music he has experienced since moving to the Us in 1995, and he expresses a preference for new dynamic styles of praise and worship. Although worship styles are also changing in Egypt, he believes it is more difficult there for Protestant worship leaders to prompt their congregations to react to contemporary Arabic worship songs. The strong influence of Coptic tradition makes some Christians hesitant to embrace "secular" sounding music within the church. Magdy concludes, however, “In America you don't feel that” (Focus Group 2011). This sense of musical freedom in American worship settings does not mean copying contemporary American churches. In Magdy's church and the other congregations I visited, a worship team, music leader, or pastor led the singing, accompanied on keyboard or guitar. Worship songs were in Arabic and followed the popular and folk music tempos Magdy refers to as baladī or maqsūm (Focus Group 2011).

Beyond the influence of its traditional worship style, the Coptic Orthodox Church as an institution is a significant reference point for Egyptian Protestants in America and in Egypt who grew up in the Coptic tradition. Some Muslim families have joined the New Jersey congregations I studied, but more new members come from Orthodox backgrounds. Some of these members continue to attend Coptic churches on holidays, while others no longer identify themselves with the Coptic Orthodox Church at all (Focus Group 2011). One woman in the Christian Arabic Church in East Brunswick explained that she used to be Coptic until she became involved in a Protestant church in Egypt and "got saved." While she now believes that Coptic Christianity is too focused on rules, she recognizes that her mother, who is a member of the non-denominational church in East Brunswick, remains attached to the Coptic Church because it represents her roots.

Two other women in the Christian Arabic Church describe themselves as committed Coptic Christians. Both mentioned the size of the Coptic Orthodox Church in their area as a reason they joined this smaller Protestant church, which they consider to be more like a family. Beyond the need for community, 
they emphasized the spiritual connection they find in the non-denominational group, which encourages personal devotion, prayer, and Bible study. For one of the women, the denominational differences do not matter, although she disagrees with the Protestant view of the saints. Nevertheless, she says, both churches nourish her faith. Attending the Coptic Church is important because she wants her children to grow up with a sense of their roots. Her friend, who gave a brief overview of Coptic history, agrees. The church has persevered through many struggles and has remained strong, she says. She hopes her children will retain this connection to the church's long history and deep tradition. While the Coptic tradition is important for some Egyptians in Arabic Protestant churches, others look to American Protestantism as a reference point instead. One young couple in the same East Brunswick church explained that they are also members of an "American church." They took this step because they are expecting a baby who will grow up speaking English and may not understand Arabic well. The non-traditional afternoon or evening service time for most Arabic congregations that rent a worship space allows members to take part in other Sunday morning services, whether they prefer the Coptic Orthodox or American Protestant worship setting.

Members of Arabic churches may locate themselves in relationship to the predominant Christian tradition in their home countries or in the Us, but according to Magdy, the Islamic culture in the Middle East also affects their sense of identity. He says many Christians in Egypt grow up learning verses from the Qur'an in their schools. This is a reminder of their status as religious minorities, but Magdy also believes Egyptian Christians internalize the "quiet" Islamic approach to religious practice. For those who grew up as religious minorities, the transition to the American Protestant context can be dramatic. Magdy explains that it takes time for immigrants to adapt to the "new way of culture" they encounter in America, where they can worship freely and feel less constrained by traditional notions about worship, whether Coptic or Islamic. In the beginning, he says, "You think like how you used to think [in Egypt]. You try to worship in a very quiet way" (Focus Group 2011). Magdy's reflections are rooted in his desire to move Arab Christians towards a more dynamic praise and worship experience, but his comments also indicate a subaltern mentality among Christian Arab minorities that does not simply disappear after immigration to a non-Islamic society.

My conversations with first and second generation immigrants of different ages and backgrounds indicate the internal diversity within their congregations and the critical relationship between a worship environment and Christian identity formation. Arab immigrants who have been in the United States for many years may express a sense of double identity, but the issue of converging cultures is especially key for a younger generation of Arab Americans who 
have lived all or most of their lives in the Us. The youth at the Arabic American Evangelical Church (AAEC) in Jersey City prefer English, in contrast to their parents who believe Arabic worship is essential. Even those young people who speak Arabic at home do not read the language well, and this limits their ability for Arabic Bible study or singing Arabic hymns. In response to this issue, AAEC created an English language youth service on Friday evenings that includes a sermon and American-style praise music. The church has also instituted what the youth described as a "hybrid service" on the one Sunday each month when the Lord's Supper is served (AAEC Youth 2011). The service includes an English children's message, Arabic music, English songs led by the youth praise band, and an Arabic sermon with an English outline projected on a screen. At this service, generational lines are clearly distinguishable by who sings during the Arabic and English songs. Nevertheless, some members of the older generation follow along in English, and children who do not read Arabic can learn the words by ear or clap to the music. Their pastor, Safwat, explains that this is one small effort toward creating common ground, and he hopes it will provide a model for families in their home lives together (Marzouk 2011).

I encountered similar inter-generational concerns when speaking with pastors, parents, and youth at other churches. In order to maintain the primary Arabic speaking church identity and to accommodate youth and young adults who are most comfortable in English, many churches have English language Sunday School or youth meetings during the regular Arabic worship service. Fouad described the situation at the Mideast Evangelical Church in Jersey City where the youth meeting takes place at the same time but is separate from the Sunday worship service. The youth join the "main church" once a month just to receive the Lord's Supper and then return to their own meeting. Some youth in his church have asked for an "American pastor" to lead them. He specifies that they do not want an Arab American pastor with perfect English but an American pastor. Because of this Fouad believes that the language barrier is not the primary issue for these youth, but rather their sense of identity as part of American culture (Focus Group 2011). The Arabic Evangelical Church of South Jersey takes another approach to these generational differences. In the single Arabic service attended by adults and youth, the pastor offers an English translation of his sermon to anyone who needs it. The youth I talked with after this service explained that they also attend a separate youth Bible study during the week.

Such efforts aim to keep the younger generation actively part of the church. During the focus group discussion with Jersey City youth and in conversations at other churches, youth group members expressed the key role their churches play in their lives. At the Arabic Evangelical Church, I spoke with the youth leader who recently took over the position after his university graduation. He 
explained that the youth group formed when he was thirteen years old and that the leadership had passed from one young man in the church to another as they grew older. Of the eighteen participants at the AAEC youth meeting in Jersey City, thirteen had already finished high school but continued to attend youth meetings consistently, and some of them came from homes as far away as Brooklyn, New York. Most of them also marked their church on their social maps as one of the most important aspects of their lives (AAEC Youth Focus Group). Like most of the AAEC youth, youth group members at the Mideast Evangelical Church, Rivers of Life, and the Arabic Evangelical Church of are all between seventeen and thirty years of age. This indicates that unmarried second generation young people remain involved in Arabic churches after high school and college (Focus Group 2011). Some parents, however, told me of their grown children who had joined English speaking congregations, and the churches I visited lacked a visible presence of second generation married couples with children.

\section{Critical Issues: Arab American Christianity and Converging} Identities

Arabic speaking churches are vital members of the body of Christ that face both challenges and opportunities as their numbers continue to grow in the Us. Like other immigrant communities, Arab Protestants are not a monolithic group, and even among Arabic congregations in New Jersey, the internal diversity is apparent. While members of Arabic churches might express a sense of negotiating between Arab and American identities, they encounter various layers of American culture as people whose identities are already shaped by multiple influences. Their transition experiences, therefore, involve a number of converging reference points. This section highlights four significant, interconnected elements that come to bear in this process of identity formation.

First, national, cultural, and religious reference points migrate alongside individuals and shape their transition experiences in a number of ways. Those who immigrate as adults have already developed a strong sense of identity. While expecting their move to America to bring practical, political, and economic changes, they may not be prepared to address the way that their new living environment is altering their sense of self. Whether identity reformation is a conscious process or not, individuals face the challenge of preserving what is most important and finding ways to pass on that heritage to their children. As is generally the case for other immigrant religious communities, Arabic speaking churches may aid in this regard by maintaining members' native language 
and traditions in a communal setting (Stepick 2005:15-16). Even for Arabs who grew up in Protestant churches in their home countries, Islamic and Eastern Christian theologies and practices may shape cultural assumptions and ways of thought. Implicit understandings of processes and negative impressions of majority religions are not easily shed in an American immigrant context. For individuals who still identify with Orthodox churches while participating in Protestant congregations, this situation is even more complex. Whether Arab Christians hold on to their previous ways of life or take intentional steps to embrace American culture, they must negotiate the pressures and influences they carry from their home contexts.

Second, in moving to the United States, Arab Christians exchange their religious minority status in the Middle East for an ethnic minority status in America. Their primary identification may now be Arab American rather than Egyptian Christian, and Arabic language worship is the defining characteristic among their churches. In New Jersey churches with a high Egyptian demographic, Arabic is the tie that binds individuals from rural and urban areas of Egypt who may have differing denominational backgrounds, theological perspectives, and educational levels. The common language also allows Protestants from other Arab countries to find a home in these churches. This linguistic grouping makes multi-national Arabic churches distinct from other immigrant churches whose language identity is attached to a particular nation.

It is important to consider what this ethno-linguistic minority status means for Arab members of the American Protestant majority. Despite historical and theological ties to American Protestants, Arab Protestant immigrants with a high level of English comprehension do not all join mainstream American churches. In Yvonne Haddad's view, the liberal theological stance that many American churches have adopted clashes with evangelical ideologies that missionaries passed on to Protestant churches in the Middle East. Among other reasons for separate "language mission churches," she cites American Christian racism and some Arab pastors' views of the moral breakdown in American churches (Haddad 1994: 72-73). While Haddad is surely correct to question church motivations and relationships between English and Arabic speaking churches in the Us, this characterization may promote an understanding of Protestants in the Middle East as mere products of conservative American missions. If taken to the extreme, such a view would deny Arabic congregations in the us the status of legitimate, independent churches by interpreting concerns for language and identity as excuses for physical separation. Theological and social differences certainly exist within denominations, and more efforts could be made to promote unity between multi-linguistic congregations. My research shows, however, that Arabic church leaders value the structure and wider con- 
nections provided by denominational affiliations and participate actively in higher church bodies. While maintaining ties with other American Protestants, worship and fellowship with Arabic speakers are essential to their transition experience.

Third, Arabic churches face a critical inter-generational dilemma. Parents who find the Arabic church an essential way to ease their own transition into American life may also look upon the church as an instrument for transmitting their culture of origin to their children. On the other hand, second generation Arab Americans place the stress on the "American" aspect of their identity and may not be as concerned with the national, religious, and cultural contexts that influence their parents. ${ }^{8}$ As Fouad put it, the youth become "American in music, in worship, in Bible study, in biblical understanding, [and] in religious devotion" (Focus Group 2011). First generation adult immigrants may see this emerging identity of the younger generation as a threat to unity within their families and churches. While cultural differences between generations can be a source of pain and conflict, these differences also provide an opportunity for churches to address issues of identity reformation in a faithful and open manner. The hybrid service at AAEC, for example, reflects the various expressions of cultural identity that are present within one congregation. This monthly Arabic-English worship service aims at the creation of a communal culture that blends rather than separates competing reference points.

Finally, while negotiating converging cultural and generational identities, Arab Americans also deal with widespread perceptions that they are not truly "American." Instances of discrimination against Arab Christians and Muslims who are viewed as a national security concern make it more difficult for Arab Americans to cultivate a sense of belonging. Although the pastors and church leaders I spoke with gave more attention to problems like church divisions and inter-generational conflicts, they also acknowledged the seriousness of antiArab racism in the United States. During the focus group meeting, Eid recognized the barriers he faces as an Arab pastor in an English speaking church. Amin mentioned the September 11 attacks and confirmed that American views of Arabs are also a concern for his congregation. He went on to describe his theological response to restore his members' sense of self and human dignity. "We are made in the image of God, whether Arabs or Caucasians", he affirmed. His sermons frequently lift up this theme (Focus Group 2011). Safwat responded to my questions about the effect of September 11 by explaining that some Arab Christians avoid discussing the subject of discrimination because

8 Such inter-generational concerns are relevant for other immigrant communities in the Us. See Stepick 2005: 19-20. 
it would mean admitting their status as ethnic minorities. He spoke of his congregation's struggle with racial predispositions transplanted from Egypt and their tendency to self-identify as whites. Arab American Christians might distance themselves from American prejudices against Muslims and emphasize their claim to whiteness by saying, "We are Christian," rather than opposing discriminatory comments (Marzouk 2011). ${ }^{9}$ While not the first concern raised in Arabic church discussions, racialized views of "Americanness" are not incidental to the lives of Arab Protestants in the Us. ${ }^{10}$

5 Conclusion

I return now to the questions posed at the beginning of this chapter regarding Arab Christian immigrants' transition experiences, reference points, and processes of identity formation. This study of five Arabic speaking congregations in New Jersey has demonstrated that Arab American Protestants' reference points vary depending on age, previous religious affiliation, or years spent in the us. Despite such differences, members of Arabic American churches experience a number of similar challenges and opportunities. For many of these immigrants, the American Protestant religious environment is a defining factor in their resettlement process. Although Arab Protestants remain a minority within the Arab American population, denominational ties and shared worship spaces with other American Protestant churches give Arabic churches a sense of belonging within the wider American culture and Protestant heritage. Arab American Protestants appreciate their connections with other Protestant churches in the Us, and they emphasize their greater freedom to worship and engage in mission and outreach, especially to Coptic Christians and Muslims. Along with the spiritual reference points Arabic churches provide their members, these churches' physical and theological connections with other American congregations help ease members' transitions to life in the us.

Given the loss of roots, language barriers, inter-generational differences, and other pressures related to immigration, church conflicts and divisions have often been part of the transition process for Arab Protestant immigrants. While internal church disputes might prompt some members to leave and join existing American churches, congregational conflicts in New Jersey have frequently led to the creation of new Arabic churches. This trend poses a major obstacle for

For the argument that some Arab Americans refuse to admit discrimination because it would present a barrier to their integration into American society, see Marvasti and McKinney 2004: 109-110.

For a comprehensive study of Arab American claims to whiteness see Gualtieri 2009. 
congregational peace and unity, but it also indicates that the Arabic church itself is an essential reference point for Arab Protestant identity in the Us. The church becomes a new cultural home where members worship in their own language and find fellowship with other immigrants. Along with a sense of belonging to a wider American Protestant community, the comfort of this familial church environment is especially important for Arabic church members facing the high levels of anti-Arab discrimination in the post-September 11 era.

In order to address the challenges and opportunities their members face in America, Arabic church leaders must know their members' religious, cultural, and national contexts and possess the ability to preach and converse in Arabic. At the same time, because of the growing second generation population, they must relate with Arab American youth for whom American culture is a primary identity marker. While the congregations in this study cater mainly to first generation immigrants, they aim to remain the spiritual home for Arab Protestants in the second generation and beyond. These churches face the critical challenge of becoming a hybrid, inter-generational place of worship that blends multiple reference points into a cohesive whole, rather than maintaining dueling Arab and American identities. Arabic churches have the opportunity to guide this process in a way that does justice to the historical circumstances and cultural realities of Arab Christians in the Middle East and the us.

Michael Suleiman argues that Arab Americans must be written into us history in order to facilitate their acceptance as fully American (Suleiman 2010: 55). Pointing to the deep roots of Arabic churches in the Us, this paper has contributed to the small amount of literature on Arab American Protestants. Much more work is required, however, to provide a comprehensive, diversified picture of Arab American Protestant experiences. A detailed history of the establishment of Arabic American churches would be one step in this direction. More in-depth studies of particular congregations would yield fruitful insight on the processes, cultural tensions, and unwritten assumptions that have affected the development of Arabic Protestant churches. There is also great potential to explore the theological expressions of migration and cultural hybridity emerging from Arabic congregations through sermons, Bible studies, liturgical practices, and communal life. Finally, future research might examine the complex issues of race, gender, and Christian-Muslim relationships that arise within Arabic churches, especially in light of differing inter-generational perspectives. Historical, sociological, ethnographical, and theological studies would be valuable for Arabic churches and would inform other American Christians about their Arab brothers and sisters in faith. This might encourage stronger relationships between English and Arabic speaking Protestant congregations and alert American Christians to the injustices of unquestioned 
assumptions about Arab Christians and Muslims in America. Increased scholarship and engagement with Arabic churches would also challenge American Christians of all ethnic and linguistic backgrounds to recognize their place within an increasingly global, transnational church.

\section{Bibliography}

Abdelsayed, Gabriel (1977). "The Coptic-Americans: A Current African Contribution." In Barbara Cunningham, ed., The New Jersey Ethnic Experience. Union City, NJ:Wm. H. Wise \& Co.: 120-130.

Ablahat, Rhoda Bertha (1937). "An Analysis of the Background, Experiences, and Needs of the Assyrian Presbyterians of Chicago with a View toward Building a More Adequate Program of Religious Education for the Carter Memorial Church." Master's thesis. Chicago, IL: Presbyterian College of Christian Education.

Ammerman, Nancy T., Jackson W. Carroll, Carl S. Dudley and William McKinney, eds. (1998). Studying Congregations: A New Handbook. Nashville: Abingdon Press.

Arab American Institute (AAI) (2002). "Religious Affiliation of Arab Americans." http:// www.aaiusa.org/page/file/b8bad613905570ea97_mghwmvb2d.pdf/ancestry.pdf. Accessed 7 February 2015 .

Arab American Institute (AAI) (2012). "National Arab American Demographics." http:// b.3cdn.net/aai/44b17815d8b386bfi6_vom6iv4b5.pdf. Accessed 7 February 2015.

Arab American Institute (AAI) (2015). "Demographics." http://www.aaiusa.org/ demographics. Accessed 7 February 2015.

Arabic American Evangelical Church Youth Group (2011). Interview with author. 15 April, Jersey City, NJ.

Asi, Maryam and Daniel Beaulieu (2013). "Arab Households in the United States: 20062010." American Community Survey Briefs May: 1-5.

Brittingham, Angela and G. Patricia de la Cruz (2003). "The Arab Population: 2000." Census 2000 Brief December: 1-12.

Faragalla, Joseph (2011). Interview with author. 13 May.

Focus Group Meeting with Arabic Church Leaders (2011). Interview with author. 13 May. Princeton, NJ.

Gualtieri, Sarah M. A. (2009). Between Arab and White: Race and Ethnicity in the Early Syrian American Diaspora. Berkeley: University of California Press.

Haddad, Yvonne Y. (1991). "The Druze in North America." The Muslim World 81, 2:111-132. Haddad, Yvonne Y. (1994). "Maintaining the Faith of the Fathers." In Ernest McCarus, ed., The Development of Arab-American Identity. Ann Arbor, MI: University of Michigan Press: 61-84. 
Hickson, Lindsay, Bradford B. Helper and Myoung Ouk Kim (2011). "The White Population: 2012." 2010 Census Briefs September: 1-20.

Holsinger, Jennifer Leila (2009). Residential Patterns of Arab Americans: Race, Ethnicity and Spatial Assimilation. El Paso, TX: L F B Scholarly Publishing.

Johnson, Todd M. and Sun Yung Chung (2004). "Tracking Global Christianity's Statistical Center of Gravity, AD 33-AD 210o." International Review of Mission 93, 369: 166-181.

Kayal, Philip M. (1977). "The Arabic-Speaking People of New Jersey: Syrians, Egyptians, Palestinians." In Barbara Cunningham, ed., The New Jersey Ethnic Experience. Union City, NJ: William H. Wise: $22-35$.

Kayal, Philip M. (1983). "Arab Christians in the United States." In Sameer Y. Abraham and Nabeel Abraham eds. Arabs in the New World: Studies on Arab-American Communities. Detroit: Wayne State University: $45^{-63}$.

Makari, Victor (2011). E-mail to author. 11 May.

Marvasti, Amir and Karyn D. McKinney (2004). Middle Eastern Lives in America. Lanham, MD: Rowman \& Littlefield.

Marzouk, Safwat (2011). Interview with author. 9 May. Princeton, NJ.

Pew Forum on Religion and Public Life (2011). "Global Christianity: A Report on the Size and Distribution of the World's Christian Population." http://www.pewforum. org/2011/12/19/global-christianity-exec. Accessed 7 February 2015.

Presbyterian Church (USA) (2011). Middle Eastern Presbyterian Congregations and Fellowships Directory 2011. Louisville, KY: Office of Middle Eastern Ministries of the PCUSA.

Salaita, Steven (2006). Anti-Arab Racism in the us: Where it Comes From and What it Means for Politics Today. Ann Arbor, MI: Pluto Press.

Sharkey, Heather J. (2012). "Middle Eastern and North African Christianity: Persisting in the Lands of Islam." In Charles E. Farhadian, ed., Introducing World Christianity. Chichester, U K: Wiley Blackwell: 7-20.

Stepick, Alex (2005). "God Is Apparently Not Dead: The Obvious, the Emergent, and the Still Unknown in Immigration and Religion." In Karen Leonard, Alex Stepick, Manuel Vasquez and Jennifer Holdaway, eds. Immigrant Faiths: Transforming Religious Life in America. New York: Altamira Press: 11-37.

Suleiman, Michael W. (1999). "Introduction: The Arab Immigrant Experience." In Michael W. Suleiman, ed., Arabs in America: Building a New Future. Philadelphia: Temple University Press: 1-21.

Suleiman, Michael W. (2006). The Arab-American Experience in the United States and Canada: A Classified, Annotated Bibliography. Ann Arbor, MI: Pierian Press.

Suleiman, Michael W. (2010). "The Arab Community in the United States: A Review and an Assessment of the State of Research and Writing on Arab-Americans." British Journal of Middle Eastern Studies 37, 1: 39-55. 